\title{
THE DIRECTIONAL DEVELOPMENT OF INTERMODAL FREIGHT CORRIDORS IN RELATION TO INLAND TERMINALS
}

This is the pre-published version of the text. The final published paper can be found at:

Wilmsmeier, G., Monios, J., Lambert, B. (2011). The directional development of intermodal

freight corridors in relation to inland terminals. Journal of Transport Geography. 19 (6):

1379-1386.

DOI: 10.1016/j.jtrangeo.2011.07.010

\begin{abstract}
This paper examines the spatial development of freight infrastructure, developing a conceptual model that draws attention to the directional development of intermodal corridors in relation to inland terminals. Two concepts of vertical control of the development process are proposed in this paper, beginning with Inside-Out, whereby inland intermodal terminals seek greater integration with their sea ports, often driven by public body intervention. By contrast, Outside-In development is displayed by the conscious use of an inland node as a tool for sea port actors (whether port authorities or terminal operators) to expand their hinterland and capture discretionary cargo.
\end{abstract}

One of the key distinctions between the two models is the role played by different government approaches to the development of inland terminal facilities. Therefore three national examples are discussed: Sweden, where the public sector is directly involved in development; Scotland, where the private sector is left to develop terminals but government encourages the process through spatial planning and modal shift funding; and the USA, where the national government has traditionally taken little action.

The primary contribution of this paper is the research agenda developed out of the conceptual model above, which should be applied to additional case studies in future work. Arising from the conceptual model and the examination of the role of public bodies is a debate on the role of regulation. However the subject of regulation is only touched upon in this paper, therefore more research is required on the government's role in infrastructure planning and regulation in order to determine the best approach in this policy area.

Keywords: Intermodal corridor, inland terminal, dry port, regulation, hinterland 


\section{INTRODUCTION}

Ports represent a complex geographical relationship with various markets. Traditionally, the hinterland of a port was physically captive, as shippers experienced few choices regarding moving cargo to and from markets. With increasingly efficient inland transport infrastructure, physical distance is no longer the sole criterion for a hinterland. Now the port's potential hinterland can be defined as the area that can be reached at a cheaper cost or shorter time than from another port. As a result, hinterlands overlap. Therefore ports and carriage providers compete to service locations in these overlapping segments. With the advent of inland terminals, inland ports and dry ports, hinterlands are now extended even further inland, adding to the complexity of the analysis of port economics and logistics activities.

The paper begins with a discussion of the literature on concepts of vertical integration and other cooperation strategies related to hinterland development. Then Taaffe et al.'s (1963) theory on spatial development is introduced and extended to include the direction from which the development is driven. The theory on directional development is then explored in the examples of Sweden, Scotland and the USA, each example chosen because of a differing role of the public sector in inland terminal development. Data were gathered from site visits and interviews at inland terminals, railroads and ports in each country, during which all interviewees were asked about the development process of freight facilities and the role of governments in this process. Literature on the relation of government policy to the development of inland terminals is then presented, in order to raise issues relevant to a potential future discussion on the possibility for government regulation in this area.

While the USA represents a different scale to Sweden and Scotland, it was included because a contrast was sought to the European model of heavy government intervention. Furthermore, it is recognised that developing countries have not been included in the sample, as the focus in this paper is on developed countries with a reasonable supply of inland terminal facilities. The study is related to conflicting models of development, rather than a case of a developing country where there may be no rail access point for hundreds of miles, therefore the difference in development options in such a case would not be as subtle as the model developed in this paper.

\section{VERTICAL CONTROL AND ITS SPATIAL IMPACT ON HINTERLANDS}

The increasing vertical integration in the supply chain has been noted in many recent papers (e.g. Heaver et al., 2000; Heaver et al., 2001; Frémont \& Soppé, 2007; Hayuth, 2007; Olivier \& Slack, 2006; Rijsenbrij, 2008; Notteboom, 2008). Van der Horst and De Langen (2008) analysed different coordination strategies within competing transport chains that have 
been adopted in order to attract or secure greater container flows, and they identify four kinds: vertical integration, partnerships, collective action and changing the incentive structure of contracts. Hayuth (2007) observed the increasing vertical integration of shipping lines in order to penetrate logistical and supply chain management, and noted that one result of this behaviour is that port choice is increasingly being determined by landside factors such as intermodal infrastructure. Therefore an opportunity exists to make profits through logistical services that can sometimes offer a better return than the maritime leg.

Discretionary cargo consists of freight that could either move to or from any inland point beyond the port's traditional geographic region. This means that the port can handle cargoes larger than its captive market area (an obvious example being Rotterdam). The additional benefits include additional service options, more cargo, and greater traffic densities which provide additional benefits for both local and distant users of a port facility. In order to analyse these flows, the terminal rather than the port has increasingly become the primary focus of study (Konings, 1996; Slack, 2007; Rijsenbrij, 2008); subsequently the land-side activities of the seaport have come under closer scrutiny (Bichou \& Gray, 2004; Parola \& Sciomachen, 2009), leading to the inevitable focus on inland terminals.

In this literature a trend may be observed towards using inland terminals to enlarge the hinterland of the sea port (going back to van Klink \& van den Berg, 1998), and the integration of logistics services within the transport chain, as inland costs (both transport and value-added services) have increased in importance to the door-to-door cost (Notteboom \& Winkelmans, 2001). Notteboom and Rodrigue (2005) noted that "the portion of inland costs in the total costs of container shipping would range from $40 \%$ to $80 \%$. Many shipping lines therefore consider inland logistics as the most vital area still left to cut costs" (p.302). Increasingly relevant is the recognition that the port's role has changed from a monopoly to a dynamic interlinkage and a subsystem in the logistics chain (Robinson, 2002).

Ports are required to drive as well as react to developments in both land and water spheres, but they have lost the means to influence events to the degree they once could. The extension of a port's influence into the hinterland is one opportunity for port authorities to intervene and better influence the future. However hierarchies in the transport chain are changing. Ports therefore need to be active in extending or even maintaining their hinterlands (Van Klink \& van den Berg, 1998; McCalla, 1999; Notteboom \& Rodrigue, 2005).

However while the economic theory of the firm examines different methods used to coordinate or control these relationships in order to reduce transaction costs (Coase, 1937), geography studies how these strategies differ across spaces and scales. Therefore in this paper 
insights derived from the theory of the firm will be combined with spatial development theory.

In this paper the aim is to build on the "main street" concept outlined by Taaffe et al. (1963), whereby "since certain centres will grow at the expense of the others, the result will be a set of high-priority linkages among the largest", p.505). In Figure 1, the large circles represents ports and inland terminals, while the smaller circles represent less significant nodes. The grey channels represent high priority corridors. Taaffe et al. (1963) do not make a distinction on the direction of development but in a historic regional development context it can be inferred that their model purely looked at development from the seaward perspective.

Figure 1. High priority 'main streets', as theorised by Taaffe et al. (1963).

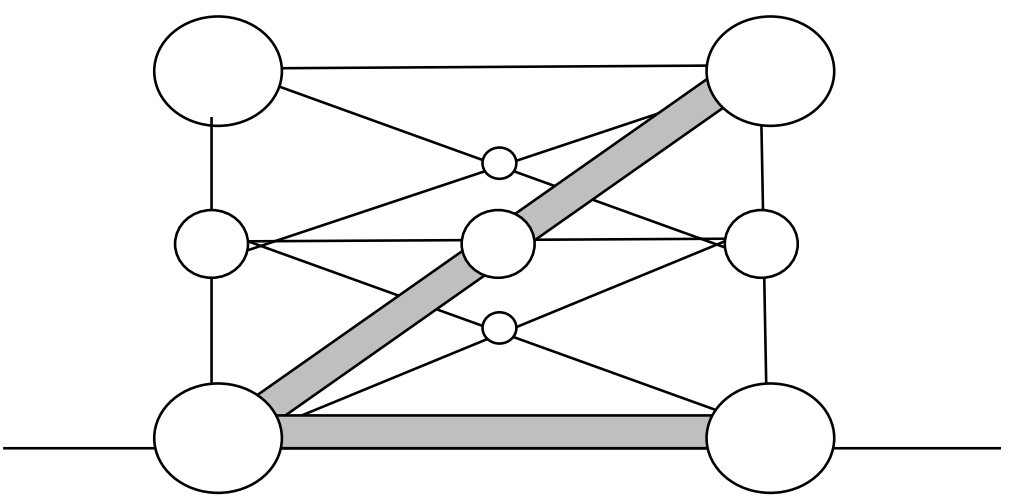

However, the relations between nodes that create priority corridors are changing. Whereas in the past these corridors were more static, due primarily to the geographical or political entry barriers represented by port location, this view of ports is no longer valid (Robinson, 2002, Bichou \& Gray, 2005). Notteboom \& Rodrigue (2005) have characterised inland terminals as active nodes in shaping the transport chain. As discussed above, these corridors are now based to a greater degree on strategies of vertical cooperation than they are on the location of physical infrastructure, due to already horizontally-integrated globalised operators seeking new methods of cost reduction and hinterland capture.

In order to supply a directional focus absent in the model of Taaffe et al. (1963), this paper borrows from the terminology of industrial organisation, which identifies backward and forward vertical integration, depending on which level of the chain owns the other levels. For example a manufacturer buying a distributor would be an example of forward integration, whereas a manufacturer buying the supplier of its raw material would be backward integration. However the focus of this paper is on the development of the sites rather than their eventual ownership or operation. Therefore in practice what are being analysed are strategies of cooperation rather than actual integration through ownership, and so the directional focus 
applied below will be based on whether control of the relationship is based on the landward or seaward side. In order to develop the focus on directional development of inland terminals, a brief discussion on recent uses of inland terminal concepts is required.

\section{INLAND TERMINALS, DRY PORTS AND THE IMPORTANCE OF DIRECTIONAL DEVELOPMENT}

Intermodal terminals in the hinterland have acquired various names over the years, such as Inland Clearance (or Container) Depot (ICD), a term that evinces a particular focus on the ability to provide customs clearance at an inland location. Similarly, the term "dry port" has been in use for decades now. It has often been used interchangeably with ICD, as well as to distinguish an inland terminal in a landlocked country from those in a country that has its own sea ports (for more on the early use of the term, see Beresford \& Dubey, 1991; Garnwa et al., 2009). Dry ports in the original discussion were generally developed from the landside towards the sea, a requirement emerging from being landlocked.

A recent academic definition of dry ports contends that "for a fully developed dry port concept the seaport or shipping companies control the rail operations" (Roso et al., 2009; p.341). Furthermore, the authors contend that "dry ports are used much more consciously than inland terminals" (ibid). Therefore this definition actually contradicts the original definition of a dry port, as it is driven from the seaward side.

Additionally, the same definition contends that the sea port and the dry port confront the user with a single interface, with the goal being to provide a smoother operation to users of both the port facility and the hinterland served by the port. This notion of an integrated system is in actuality identical to the extended gate concept (see Monios [2011] for a more detailed discussion of this point).

More recently, the term "dry port" has been used in industry as a marketing tool, perhaps to imply that an inland facility has reached a particular level of sophistication in terms of services offered, such as customs or the presence of Third Party Logistics (3PL) firms within the site and/or an adjoining freight village or similar (see also GVZ in Germany, ZAL in Spain, interporti in Italy).

As these two definitions of dry ports can be seen to contradict with regard to drivers and directions of development, this paper introduces the directional concept, borrowing from the directional terminology in industrial organisation theory. This approach allows comparisons to be made between terminals that are developed from the seaward side and those that are developed from the landside. 
The authors therefore make a distinction between two types of development: Inside-Out and Outside-In. Inside-Out describes a situation where the development of the inland facility may be driven by an inland carriage company (e.g. railroad, barge, logistics service provider) or a public body (more on this below), while an Outside-In arrangement may be developed by port authorities, port terminal operators or ocean carriers.

Figure 2. Two Directions of Development.

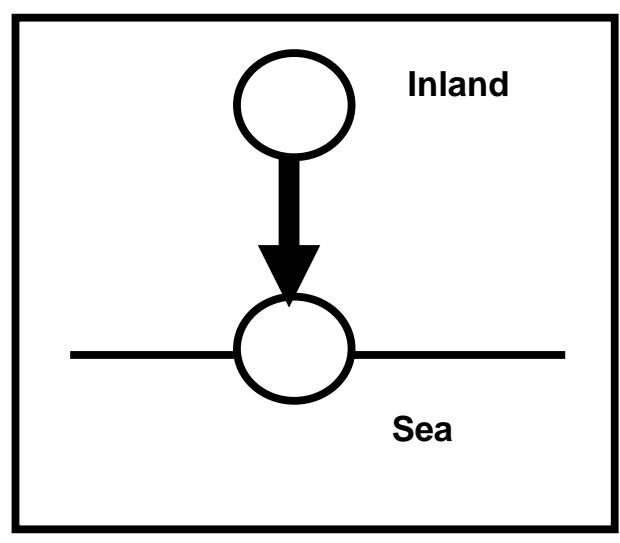

(a) Inside-Out

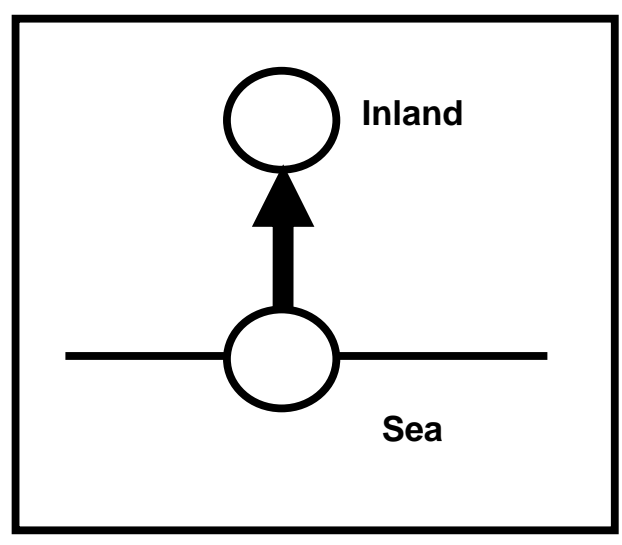

(b) Outside-In

One example of Outside-In development, driven from the seaward side, is Rotterdam sea port terminal operator ECT vertically integrating inland through the purchase of terminals at Venlo, Willebroek and Duisburg. On a similar note, the ports of Rotterdam and Antwerp have recently expressed interest in buying shares in the inland port of Duisburg (Lloyd's List, 2011). A public sector alternative is demonstrated in Spain, where for example port authorities such as Barcelona are investing in inland terminals in the Spanish hinterland (e.g. Madrid/Coslada, Azuqueca de Henares and Zaragoza) as well as developing transport services across the French border such as the rail link to Lyon (Monios, 2011). The ECT example shows how a private sector company can expand its industry position through integration strategies, while the Spanish case demonstrates the use of joint ventures between public and private bodies to achieve a common goal, both being developed Outside-In.

Inside-Out development happens when inland intermodal terminals, usually operated by rail or logistics companies, in many cases subsidiaries of nationally-owned rail companies (Notteboom, 2008), are developed with the aim of facilitating trade by attracting flows to that region and a specific corridor. This is often done by attempting close cooperation strategies with a specific port and often driven by public organisations.

Now that ports are becoming somewhat more concerned about the possibility of losing power by being bypassed through direct deals made between shipping lines (or shippers) and inland terminals, they are increasingly seeking to secure their hinterland through active 
cooperation with inland terminals, i.e. Outside-In. What is interesting from the point of view of this paper is the direction of development in order to be competitive in a particular hinterland. Some are developed with a directional intention from the start, while others begin as conventional inland intermodal terminals and later become more integrated with sea ports.

Taaffe et al. (1963) derived their model when ports were public entities. How has the situation changed since then, now that we have privately-operated (and privately-owned in some cases) ports? Furthermore, Taaffe et al. (1963) were referring to transport corridors that have developed naturally. How is the situation changed if government intervention creates an artificial priority corridor? What about the influence of modal shift policies, or the lack of them? The multi-billion euro Betuweroute connecting Rotterdam with Germany is one example of an artificial priority corridor. Conversely, allowing a motorway to be built next to a rail line results in freight traffic shifting mode in the other direction (e.g. 'Rollende Landstrasse' (RoLa) between Dresden, Germany and Lobositz, Czech Republic). If all nodes in a transport chain are operated by the public sector then integration should be easier, however it may be inefficient if there is no competition. Whereas on the other hand, competition in a limited area that cannot sustain more than one profitable venture can be detrimental to the potential for modal shift and its economic viability as well as its environmental impact. The question asked in this paper is how are Taaffe's 'main streets' or priority corridors being dealt with under modern conditions?

A key component of the directional development model proposed in this paper is the role of the public sector in the development process. Recent research (Notteboom \& Rodrigue, 2009; Rodrigue at el., 2010) has suggested that developments driven by the public sector due to motivations of regional development can run the risk of over-supply, while in North America the private sector focus on profit tends to regulate this problem. The case studies below will serve to strengthen these findings, as well as allowing insight into related regulatory issues that are also raised by the same authors.

\section{INTERNATIONAL EXPERIENCES}

In the following sections, recent developments and potential future results in vertical cooperation and inland terminal development are discussed for the cases of Sweden, Scotland and the USA. In Sweden, the public sector is directly involved in development; in Scotland, the private sector is left to develop terminals but government encourages the process through spatial planning and modal shift funding; and in the USA the government has traditionally taken little action, although funding programmes are now available to support new developments. 


\subsection{Sweden}

In Sweden inland terminals can be built and owned by municipalities. The interest of municipalities is in improving the transport chain, thus hoping to achieve twin aims: increasing modal shift thus benefitting the environment, and increased attractiveness for businesses to locate in the area, thus creating jobs and economic development in the municipality and region. Sweden is therefore a clear case of Inside-Out development, although interestingly, while the developments are driven from the perspective of the inland terminal site, the municipalities are not seeking to control the flows themselves; indeed they seek actively to accommodate the port.

Over the last decade, the number of rail terminals in Sweden has grown (Gothenburg is now connected by rail to 25 terminal locations), and recently some of these terminals (e.g. Eskilstuna) have begun to use the term "dry port" in their name. However none of these terminals fit either of the dry port definitions referenced earlier, demonstrating how the term can be used in industry without precise meaning.

In the past, the Port of Gothenburg has not needed to be proactive in developing terminals to extend its hinterland because other actors have been motivated to implement inland terminals themselves. Recently, the sea port has become more interested in a share of control in the terminal operations. In return, the inland terminals gain brand association and greater integration with the sea port, which it is hoped will be developed over time into greater IT integration resulting in efficiency gains for the entire transport chain. This finding substantiates the contention of Notteboom \& Rodrigue (2010) that port authorities have in the past been afraid of competition with inland terminals but some are recognising that there are many benefits to cooperation.

This (initially small) level of vertical cooperation, whereby inland terminals are constructed with the expectation of becoming integrated with their sea ports, results from the motivation of the municipality, which is not simply to make money. Therefore the sea port has a degree of negotiating power because the municipalities have less motivation to sign deals with competing ports. However the sea ports are now realising that increased cooperation with inland terminals is in their own interest. Indeed, it may be that they have realised that they need to sign deals with terminals to control container positioning before shipping lines bypass the sea port and sign deals directly with the inland terminals themselves, therefore directly controlling their own hinterland access.

Yet because terminals are approved and built by municipalities rather than at the regional level, problems have arisen with a number of municipalities desiring to build terminals in an 
area that is not large enough to provide the minimum efficient scale for more than one terminal. Detailed coverage of this issue is provided by Bergqvist (2007) and Bergqvist et al. (2010). Without powers at a regional or national level to regulate terminal implementation, these situations cannot be prevented; nor can they be solved unless a municipality is willing to be the first one to back down.

Regulation at a higher level could help to address this challenge in terms of overall efficiency of the system, as the current situation may impede the potential to reach a level of modal shift that would deliver towards goals of emissions reductions. However, the situation may already have progressed past that point. Municipal terminals are generally assisted with some government aid, whether through one-off national grants towards modal shift or through part-finance by the rail authority to build connections to the mainline. Now that terminals are oversupplied in some areas, this co-financing will not be forthcoming, and thus to a degree the situation can be said to be self-regulating. Dangers remain in regions currently undersupplied with terminals, in which individual municipalities compete to build terminals that would then split the necessary economies of scale, however it remains the task of the sub-regional and regional administrators to bring municipalities together and facilitate cooperation in their infrastructure development. This is done by utilising the Swedish regional political model that aims for consensus amongst all municipalities rather than for instance taking a majority vote and imposing the result from the top down.

\section{What is the future of inland terminal facilities?}

The future for Sweden would appear to consist of greater cooperation between sea ports and inland terminals, however it remains to be seen if the situation will be affected by greater interest on behalf of shipping lines regarding the inland distribution of their containers. Similarly, it is the development of logistics zones around terminal sites (particularly the sale of earmarked land within development sites to producers or logistics firms) that may determine whether more shippers accommodate themselves to the growing network of rail hubs, leading to higher train fill rates, increased economies of scale, and a snowball effect of a greater modal share for rail in Sweden.

\subsection{Scotland}

In terms of the model developed above, Scotland's inland terminals represent Inside-Out development, having been developed to provide access to global transport corridors via large ports in the south-eastern UK. The sites were built when the rail industry was owned and operated by the national rail operator. There is little evidence of Scottish ports seeking to 
capture hinterlands through closer relationships with inland terminals, and the main intermodal container terminal in Scotland (the Freightliner terminal at Coatbridge, outside Glasgow) receives the majority of its containers from ports in Southeast England, while at the same time it is not being served by any rail service to or from Scottish ports (Baird et al., 2010).

Unlike Sweden, in Scotland public authorities do not build infrastructure themselves; their influence is felt primarily through the planning system. Transport planners in local authorities or Regional Transport Partnerships develop Local and Regional Transport Strategies but terminals do not come under their funding capabilities. Therefore they can instruct research and facilitate private sector investment but cannot be proactive in developing a terminal site the way Swedish municipalities can. Drafting plans and researching feasibility as a precursor to encouraging the private sector to build a terminal cannot guarantee bringing a project to fruition. They can only suggest and encourage and by identifying projects as strategic, use favourable planning permission to stimulate a project. Modal shift grants can however be applied for on a case by case basis (based solely on annual levels of road miles removed).

Modal shift funding in Scotland is however complicated by the fact that it must be based on the shift of existing road flows. A multi-user terminal operator cannot qualify for this funding because it is the individual operator or logistics provider that is carrying the traffic. Furthermore, if a new site is developed then there is no existing flow to shift therefore funding cannot be sought. These represent two reasons (amongst others) why the majority of the annual modal shift budget remains unspent year after year (e.g. $£ 3.7 \mathrm{~m}$ spent out of a budget of $£ 15.4 \mathrm{~m}$ in 2008/9 [Monios, 2010]).

However the advantage of leaving the decisions to the private sector means a new terminal would not be built within the hinterland of a first terminal unless investors were convinced of the feasibility in advance. Therefore regional stimulation through public sector investment is less likely, but failed projects are also less likely. As private sector ports in Scotland are mainly risk averse regarding developments in vertical cooperation, both the Inside-Out and Outside-In models have basically been absent since rail and port sector privatisation.

\section{What is the future of inland terminal facilities?}

The future for intermodal terminals in Scotland is likely to relate more to greater cooperation between existing sites than the development of a new site. The Mossend site which was developed as the Scottish hub for the Channel Tunnel is underused, and when combined with smaller sites at Hillington and Elderslie, the existing terminal capacity in the 
central belt looks sufficient. With increased coordination of flows to Aberdeen and Inverness, the Scottish network currently has little need of a new terminal. Existing capacity can be filled by a few approaches, such as better balancing of flows to and from England (e.g. strategies for sourcing backhauls and repositioning empties), attracting large customers such as supermarkets to build depots on rail-connected sites, and a more efficient management system (including "co-opetition" amongst carriers [Song, 2002]) that can match demand and supply to help attract smaller customers. Greater collaboration within the Scottish network can help to attract maritime flows directly to Scottish ports, leading to a better integrated system in the future (Monios \& Wilmsmeier, 2011).

The most recent detailed government statement with regard to freight transport was contained in the Freight Action Plan for Scotland (Scottish Executive, 2006b), which was based on the Scottish Freight Strategy Scoping Study (WSP, 2006), a large consultation with stakeholders in the freight industry. Perhaps the key action resulting from the white paper was the commencement of the Strategic Transport Projects Review (Transport Scotland, 2009). The projects identified in this review were incorporated into the second National Planning Framework (Scottish Government, 2009). Designation of a project in this document as a "national development" implies that there is less risk for the private sector to get involved in developing projects that relate to these sites, thus investment should be encouraged. Disappointingly, however, funding strategies for these developments are unclear and will only be considered after the multi-billion pound commitment to the new Forth crossing has been accommodated. It is clearly stated that "this is not a spending document" (p2), and while it claims that "Planning authorities are required to take the Framework into account when preparing development plans and it is a material consideration in the determining of planning applications" (p1), the vagueness of this statement underlines the difficulty in developing public policy for privately operated facilities.

The document also referred to recently-commissioned government research on "sustainable freight facilities" (p.53), a statement that harks back to a report produced on behalf of the government in 2002, which analysed the funding system for modal shift infrastructure grants and recommended that a more proactive and strategic approach be taken by government rather than simply waiting for ad hoc funding applications. The report suggested that the government identify and part-fund sustainable distribution facilities, effectively taking the risk from the private sector (MDS Transmodal, 2002). The Scottish Multi-Modal Freight Locations Study (Scott Wilson, 2009) has now been completed, and it identified development issues at a number of freight terminals throughout Scotland, and noted where investment would be needed either to bring old sites into operation or to enable existing 
sites to handle forecast increases in freight traffic up to 2020. Again, however, commitments to develop these sites have not been forthcoming from either the public or the private sector.

\subsection{The USA}

Although container operations were developing in the 1960s and 1970s, several laws passed in the early 1980s allowed for cooperation between different transportation groups to develop. One law was the Staggers Act of 1980, which partially deregulated some areas of the railroad industry, increasing the railroad's ability to react flexibly to market needs. These changes were designed to make the railroads more competitive for long distance domestic freight that had been lost to truck companies during the 1970s. The Shipping Act of 1984 relaxed many restrictions faced by the carrier operators and allowed an ocean carrier to provide inland distribution on a single through bill of lading.

Traditionally, US intermodalism referred to discretionary cargos destined for areas east of the Rockies, but that arrived along the West Coast. They are truly discretionary, as any West Coast or East Coast port that possesses the adequate facilities and services to satisfy a shipper's needs could receive this cargo. For the Eastern United States, intermodal traffic has been developing, but not with comparable volumes to cargo moving off the West Coast into the Eastern US. Today, there are reverse land bridge flows, with some speculation about the magnitude of intermodal diversion from the West Coast to the Eastern US after the expansion of the Panama Canal, which will have implications for the development of inland ports in the Eastern US.

During the mid 1980s, APL formed the first Transcontinental double stack train services, recognising that an intermodal routing provided a ten day service advantage over an all-water service through the Panama Canal to New York. While the transit time was important, APL also offered more services to the shipper as the customer could receive a single through bill of lading while knowing that APL had committed service schedules to deliver the cargo.

The growth of discretionary cargoes allowed APL and other shipping lines to expand their capacity in the Transpacific. By using larger, faster ships, a carrier could offer a fixed, weekly sailing schedule, while the additional capacity reduced per unit costs. With the double stack train, these new services were competitive because they increased the amount of revenue that each unit train could generate, provided a shipper with a single through bill of lading and lowered the net cost of inland transportation.

The intermodal terminals that received these cargos were initially railroad terminals, mostly located in urban areas. Over time, these rail terminals have expanded to provide services, but there are ownership issues that limit the true development of inland ports. For 
one, the majority of the railroad tracks are owned by Class I railroads (these represent the largest railroad operators in North America.) These services also led to increased penetration of railroads into several domestic corridors, as ocean carriers secured backhaul cargos to reposition empty containers to the West Coast ports by moving domestic cargos and transloading them in the port region.

The US did not find it necessary to have extensive publically funded inland port facilities, as the railroads provide contracts with the shipping companies for carriage services between port areas and hinterland terminals. Along the West Coast, given the limited number of gateway locations (Southern California, the Bay Area, and the Pacific Northwest), the rail services treat each region as a traffic generation area, and while there exist several ports in each of the ranges, the ports are seen as simply gateway facilities. Any discussions between the ports and the railroads are operational, not strategic, with the exception of the Alameda Corridor, which involved consolidating rail tracks to improve overall system efficiencies in the Los Angeles area.

While most intermodal terminals in the United States are part of privately owned and operated rail networks, the Virginia Port Authority (VPA) operates the Virginia Inland Port, located in Front Royal, Virginia, which represents a proactive public approach. This site was developed to promote regional economic activity as well as reduce transportation costs for shippers in the region. Opened in 1989, VPA currently operates five train moves weekly between the inland port and the Hampton Roads area, and provides customs, coast guard, and related support services to assist regional shippers. The majority of the funding for the project came from port operating costs, and not necessarily direct state funding.

\section{What is the future of inland terminal facilities?}

There are several signs that inland port concepts are developing in the United States. The largest is the development of the Heartland Intermodal Corridor. The corridor, linking the Hampton Roads area to Columbus Ohio, and eventually to Chicago, represents the first multistate private-public intermodal corridor in the US. The work involves upgrading an existing coal line with restricted dimensions to handle international maritime and domestic double-stack container traffic moving from the Virginia Port Authority west through Virginia, West Virginia, and Ohio, continuing to Chicago and its interchanges with the western Class I railroads. A key advance of the project was establishing an unprecedented funding mechanism that allowed money to flow directly to the railroads from the federal government.

The project affords a significant competitive advantage to Virginia's ports by providing a shorter (by several hundred miles) and faster route to the Midwest along with high-speed 
double-stack capacities. It also benefits communities along the route through Virginia, West Virginia, and Ohio by providing economic development and transportation opportunities. Project funding is coming from both public sources (Virginia Rail Enhancement Grant and Ohio Rail Development Commission Grant) and the private sector (Norfolk Southern Corporation). Within this same corridor, an intermodal terminal is being developed at Prichard West Virginia Intermodal Terminal to provide access to shippers within the Tristate area around Huntington, West Virginia. The Heartland Corridor represents a case of InsideOut development, where a region with poor access to global transport corridors has succeeded in developing a new intermodal corridor to serve its shippers. This model is in contrast to the Outside-In model exemplified by Virginia Inland Port, which is an initiative taken by the port in order to manage its container flows through a high-capacity link.

While not rail corridors as mentioned earlier, several short sea shipping or container on barge operations have been explored in the US. This includes the recent 64 Express, which operates a barge service between Richmond, Virginia and the Hampton Roads area. The failed New York to Albany Port inland water service represents an example of misaligning an intermodal corridor project without securing committed partners. While the service did attract cargoes, once the operating subsidy ended, the service was unable to operate profitably and ceased operations.

Given the lessons learned, the United States Government is currently exploring the importance of examining and improving operations along freight corridors for the next bill authorising the nation's highway transportation. The Federal Highway Administration does operate a program for funding projects of national significance, but these projects do not necessarily support international cargos moving through inland facilities. There are discussions about examining multimodal corridors to manage highway traffic, emissions, and related externalities associated with commercial freight movement, but these research efforts are still in their infancy.

\section{THE IMPACTS OF DIRECTION ON INLAND TERMINAL DEVELOPMENT}

The three case studies above show the relevance of adding a direction of development to Taaffe's "main street" concept for the case of inland terminal development. A main finding is that the direction of development (Inside-Out or Outside-In) significantly depends on the existence of policies promoting proactive behaviour, whether by the public or private sector. In the majority of cases above, Inside-Out development has been led by public organisations, with mixed results. The case of Scotland shows how a lack of strategy and actors being risk averse has basically left 'deserted main streets' and, as seen in other sectors, the revitalisation 
of 'deprived' areas might require greater collaboration efforts rather than attempting to build a new system from scratch. In the United States, independent terminal development results from the fact that $89 \%$ of freight moved in the country is domestic (FHA, 2010), therefore the rail operators have a strong focus on the interior rather than being developed as satellite terminals for sea ports. Besides the mostly independent model followed in the US, the case study above has identified market-driven Outside-In development of an integrated inland port facility at VIP, as well as public-sector-driven Inside-Out development via the Heartland Corridor and its inland port site at Rickenbacker (outside Columbus, Ohio).

Furthermore, the role of the public sector in facilitating and driving development from the inside out creates new opportunities in linking ports to inland terminals. The Swedish system takes on the risk for the private sector in order to accelerate development that might otherwise take many years. The disadvantage is, as shown above, that there remains a danger of numerous municipalities pursuing projects that through destructive competition and diluted economies of scale become unviable.

The ultimate goal of cooperation strategies such as vertical integration, in combination with a change in the spatial reach of an operation, is to decrease costs and/or increase market share. The difficulty is that freight terminals are natural monopolies up to a certain flow level in a defined area, therefore they could be regulated by a government body or association, rather than being regulated through competition. This would be in addition to existing transportation regulatory activities concerning rates and contracting activities. However, transport corridors have a spatial reach that usually exceeds local or state government influence. In Europe it might even exceed the influence of national governments, a situation comparable to state level in the USA. Consequently, it is difficult to regulate and direct hinterland developments in a way that achieves public sector aims. Examples have already been given of ECT's integrated network from the Netherlands to Belgium and Germany, and an even better example is the publicly-owned port of Barcelona attempting to develop services to ZAL Toulouse.

\section{PRELIMINARY DISCUSSION ON THE ROLE OF GOVERNMENT POLICY}

The differentiation between Inside-Out and Outside-In contributes to the understanding of the complex discussion regarding policies supporting the development of inland terminals, as the actors and their overall strategies and aims are potentially different, as might be the impact on levels of competition. The paper also raises the potential role of government strategies for regulating inland terminal development, a large subject that cannot be answered by the limited 
data presented here, and in any case is not the focus of the conceptual model developed in this paper. However some preliminary conclusions can be drawn.

It may be that Outside-In development of inland terminals is rare because port actors (port authorities, terminal operators or shipping lines) have not found it necessary to do so in order to promote their interests. As seen in the case studies, many other actors are motivated to develop facilities. By contrast, Inside-Out development appears to be the most common, particularly in the case of public sector initiatives. The problem in this case is the misalignment of priorities at different scales. National governments (or indeed supra-national institutions at the EU level) announce their priorities of promoting intermodal freight facilities, yet when the decisions are being made by individual municipalities or regions, the danger of subsidising sub-optimal facilities needs to be addressed.

Transport geography has tended to be less theoretical than economic geography (Hall et al., 2006), and while issues such as regulation and the role of institutions have been raised in this paper, the focus is firmly on the transport aspects of spatial development. However some treatment of these issues can be found in the transport geography literature.

Van Klink \& van den Berg (1998) studied the subsidisation of start-up costs for freight rail shuttles to ports as well as cooperation to achieve economies of scale, and concluded that 'EU regulation forbidding cartels and national subsidies is working as a barrier to the development of intermodal transport' (p.4). Baird (2004) considered whether the 'public good' justification for government investment in seaports is valid, especially within a common EU market, and this argument can also be applied to intermodal terminals. Therefore the role of government support in the implementation of intermodal terminals is not clear. Development decisions need to be based on an analysis of whether implementing an inland terminal is simply a protectionist measure that would prop up a failing sea port or whether it will be planned as a node in an integrated terminal system (as argued by Cullinane \& Wilmsmeier, 2011). Ng and Gujar (2009a\&b) discussed different measures taken by the Indian government to direct inland terminal development, some resulting in artificial transport chains that would not otherwise exist.

In terms of planning, Slack (1999) suggested that some sort of government regulation may be required in the USA to prevent what he calls "satellite terminals" from appearing on an ad hoc basis rather than being identified and planned strategically. In the UK, Pettit (2008) noted that the lack of a national policy for strategic port development has meant that "in the recent past, it is the development planning system that has had most impact on determining the development of UK ports" (p.723). 
As far back as 1996, Höltgen observed concerns in Europe with the proliferation of freight terminals that were not part of strategic planning frameworks (Höltgen, 1996). More recently, Bergqvist \& Wilmsmeier (2009) noted that intermodal terminals are being developed on an ad hoc basis and this development could threaten their efficiency and hence potential for modal shift. They suggest that government policy could be required to enable a planned and therefore integrated system of inland terminals in ideal locations linked by high quality transport infrastructure. The requirement for any facility that benefits from such legislation would be that they remain a common user facility, and publish a transparent pricing structure. They likewise suggest that inland terminals become eligible for EU Marco Polo funding, again on the basis of transparency to encourage modal shift. Similarly, Woxenius \& Bärthel (2008) discussed the idea that terminals could be considered infrastructure rather than operations, thus making it simpler for them to be implemented through government subsidy and then operated by the private sector. Notteboom (2007) suggested some measures that regulators can take to lower entry barriers in terminal operations.

\section{RECOMMENDATIONS FOR FUTURE WORK}

The issues arising from the research in this paper suggest that a full study on the regulatory aspects of inland terminal development should be undertaken, particularly in the context of a much-needed review of European Union subsidies for transport infrastructure. A suspected misalignment of transport policies across spatial scales needs to be investigated.

In terms of developing a model of spatial directional development as proposed in this paper, further research is also required to develop the research agenda of port-hinterland development. This could particularly involve a revision and discussion of the port regionalization concept (Notteboom \& Rodrigue, 2005), in which insufficient attention was paid to the drivers and direction of development.

This paper contributes to greater clarification of intermodal terminal taxonomies such as dry ports and extended gates, however further research should discuss policies of increased integration between sea ports and inland nodes in more detail. Further, what cooperation strategies are pursued in development of successful inland terminals and what issues are raised, both for the company and for governments or regulators? An additional aspect is to what extent the direction of the cooperation strategy followed during development influences the potential integration of partners once the site is operational.

Another issue that requires further investigation is security in intermodal transport chains through greater integration of transport corridors, which is not covered in this paper. Increased requirements for transportation security could benefit from the associated transparency of 
moving cargo through dedicated intermodal corridors. What levels of collaboration are optimal, and should they develop as Inside-Out or Outside-In? What role, if any, should governments play in facilitating or regulating these developments?

\section{ACKNOWLEDGEMENTS}

Research in Scotland and Sweden was undertaken with the financial support of the Interreg IVb North Sea Region-funded Dryport project.

\section{REFERENCES}

Baird, A. J., 2004. Public goods and the public financing of major European seaports. Maritime Policy \& Management 31(4), 375-391.

Baird, A. J., Monios, J., Wilmsmeier, G., Mathie, I., 2010. Unitised freight flows, logistics strategies and Scotland's external trade. Paper presented at the European Conference on Transport, Glasgow, October 2010.

Beresford, A. K. C. and Dubey, R. C., 1991. Handbook on the management and operation of dry ports. RDP/LDC/7. Geneva, Switzerland: UNCTAD.

Bergqvist, R., 2008. Realising logistics opportunities in a public-private collaborative setting: the story of Skaraborg. Transport Reviews 28(2), 219-237.

Bergqvist, R., Falkemark, G., Woxenius, J., 2010. Establishing intermodal terminals. World Review of Intermodal Transportation Research. 3(3): 285-302.

Bergqvist, R. and Wilmsmeier, G., 2009. Extending the role and concept of dryports: A response to the public consultation of "A sustainable future for transport: Towards an integrated, technology-led and user friendly system" by the Dryport project.

Bichou, K. and Gray, R., 2004. A logistics and supply chain management approach to port performance measurement. Maritime Policy \& Management 31(1), 47-67.

Bichou, K. and Gray, R., 2005. A critical review of conventional terminology for classifying seaports. Transportation Research Part A: Policy and Practice 39(1), 75-92.

Coase, R. H., 1937. The nature of the firm. Economica. 4 (16): 386-405.

Cullinane, K., Wilmsmeier, G., 2011. The Contribution of the Dry Port Concept to the Extension of Port Life Cycles. In: J. W. Böse (Ed), Handbook of Terminal Planning, Springer, New York.

FHA, 2010. Freight Facts and Figures 2010.

http://ops.fhwa.dot.gov/freight/freight_analysis/nat_freight_stats/docs/10factsfigures/pdfs/fff2 010_highres.pdf Accessed February 22, 2011. 
Frémont, A. and Soppé, M., 2007. Northern European range: shipping line concentration and port hierarchy. In: Wang, J., Olivier, D., Notteboom, T. and Slack, B., (Eds), Ports, Cities and Global Supply Chains. Aldershot: Ashgate, pp. 105-120.

Garnwa, P., Beresford, A. and Pettit, S., 2009. Dry ports: a comparative study of the United Kingdom and Nigeria. In: Transport and Communications Bulletin for Asia and the Pacific No. 78: Development of Dry Ports. New York: UNESCAP.

Hall, P., Hesse, M., Rodrigue, J-P., 2006. Reexploring the interface between economic and transport geography. Environment \& Planning A. 38 (7): 1401-1408.

Hayuth, Y., 2007. Globalisation and the port-urban interface: conflicts and opportunities. In: Wang, J., Olivier, D., Notteboom, T. and Slack, B., (Eds), Ports, Cities and Global Supply Chains. Aldershot: Ashgate, pp. 141-156.

Heaver, T., Meersman, H., Moglia, F., Van de Voorde, E., 2000. Do mergers and alliances influence European shipping and port competition? Maritime Policy \& Management 27(4), 363-373.

Heaver, T., Meersman, H., Van de Voorde, E., 2001. Co-operation and competition in international container transport: strategies for ports. Maritime Policy \& Management 28(3), 293-305.

Höltgen, D., 1996. Intermodal Terminals in the Trans-European Network. Discussion Paper, European Centre for Infrastructure Studies, Rotterdam.

Konings, J. W., 1996. Integrated centres for the transhipment, storage, collection and distribution of goods. Transport Policy 3(1): 3-11.

Lloyd's List, 2011. Rotterdam and Antwerp target Duisburg stake. 14 ${ }^{\text {th }}$ Jan 2011. http://www.lloydslist.com/11/sector/ports-and-logistics/article354037.ece Accessed 19th Jan 2011.

McCalla, R. J., 1999. Global change, local pain: intermodal seaport terminals and their service areas. Journal of Transport Geography 7(4), 247-254.

MDS Transmodal Ltd., 2002. Opportunities for developing sustainable freight facilities in Scotland. Report prepared for the Scottish Executive, Edinburgh.

Monios, J., 2010. The effect of maritime policy and funding on short haul shipping in Scotland. Paper presented at WCTR, Lisbon, Portugal, July 2010.

Monios, J., 2011. The role of inland terminal development in the hinterland access strategies of Spanish ports. Research in Transportation Economics, forthcoming.

Monios, J., Wilmsmeier, G., 2011. Dry ports, port centric logistics and offshore logistics hubs: strategies to overcome double peripherality? Maritime Policy and Management, forthcoming. 
Ng, K. Y. A. and Gujar, G. C., 2009a. The spatial characteristics of inland transport hubs: evidences from Southern India. Journal of Transport Geography 17(5), 346-356.

Ng, K. Y. A. and Gujar, G. C., 2009b. Government policies, efficiency and competitiveness: the case of dry ports in India. Transport Policy 16(5), 232-239.

Notteboom, T., 2007. The changing face of the terminal operator business: lessons for the regulator. Paper presented at ACCC Regulatory Conference, Gold Coast, Australia, July, 2007.

Notteboom, T., 2008. Bundling of freight flows and hinterland network developments. In: Konings, R., Priemus, H. and Nijkamp, P., (Eds), The Future of Intermodal Freight Transport. Cheltenham: Edward Elgar, pp. 66-88.

Notteboom, T. E. and Rodrigue, J., 2005. Port regionalization: towards a new phase in port development. Maritime Policy \& Management 32(3), 297-313.

Notteboom, T. E. and Rodrigue, J-P., 2009. Inland terminals within North American \& European Supply Chains. In: Transport and Communications Bulletin for Asia and the Pacific No. 78: Development of Dry Ports. New York: UNESCAP.

Notteboom, T. E. and Winklemans, W., 2001. Structural changes in logistics: how will port authorities face the challenge? Maritime Policy \& Management 28(1), 71-89.

Olivier, D. and Slack, B., 2006. Rethinking the port. Environment \& Planning A 38(8), 14091427.

Parola, F. and Sciomachen, A., 2009. Modal split evaluation of a maritime container terminal. Maritime Economics \& Logistics 11(1), 77-97.

Pettit, S. J., 2008). United Kingdom ports policy: Changing government attitudes. Marine Policy 32(4), 719-727.

Rijsenbrij, J., 2008. Container handling in mainports: a dilemma about future scales. In: Konings, R., Priemus, H. and Nijkamp, P., (Eds), The Future of Intermodal Freight Transport. Cheltenham: Edward Elgar, pp. 109-134.

Roe, M., 2007. Shipping, policy \& multi-level governance. Maritime Economics \& Logistics 9(1), 84-103.

Robinson, R., 2002. Ports as elements in value-driven chain systems: the new paradigm.

Maritime Policy \& Management. 29 (3): 241-255.

Rodrigue, J-P., Debrie, J., Fremont, A. and Gouvernal, E., 2010. Functions and actors of inland ports: European and North American dynamics. Journal of Transport Geography, forthcoming.

Roso, V., Woxenius, J. and Lumsden, K., 2009. The dry port concept: connecting container seaports with the hinterland. Journal of Transport Geography 17(5), 338-345. 
Scottish Executive, 2006. Freight Action Plan for Scotland. Edinburgh: Scottish Executive.

Scottish Government, 2009. National Planning Framework. Edinburgh: Scottish Government.

Scott Wilson, 2009. SEStran Freight Routing Strategy. Report prepared for SEStran, Edinburgh.

Slack, B., 1999. Satellite terminals: a local solution to hub congestion? Journal of Transport Geography 7(4), 241-246.

Slack, B., 2007. The terminalisation of seaports. In: Wang, J., Olivier, D., Notteboom, T. and Slack, B., (Eds), Ports, Cities and Global Supply Chains. Aldershot: Ashgate, pp. 41-50.

Song, D-W., 2002. Regional container port competition and co-operation: the case of Hong Kong and South China. Journal of Transport Geography 10(2), 99-110.

Taaffe, E. J., Morrill, R. L. and Gould, P. R., 1963. Transport expansion in underdeveloped countries: a comparative analysis. Geographical Review 53(4), 503-529.

Transport Scotland, 2009. Strategic Transport Projects Review. Edinburgh: Transport Scotland.

Van der Horst, M. R. and De Langen, P. W., 2008. Coordination in hinterland transportchains: a major challenge for the seaport community. Maritime Economics \& Logistics 10(1-2), 108-129.

van Klink, H. A. and van den Berg, G. C., 1998. Gateways \& Intermodalism. Journal of Transport Geography 6(1), 1-9.

Woxenius, J. and Bärthel, F., 2008. Intermodal road-rail transport in the European Union. In:

Konings, R., Priemus, H. and Nijkamp, P., (Eds) The Future of Intermodal Freight Transport. Cheltenham: Edward Elgar, pp. 13-33.

WSP, 2006. Scottish Freight Strategy Scoping Study. Report prepared for the Scottish Executive, Edinburgh. 